\title{
DELAY FACTORS ON THE ADMINISTRATION OF THROMBOLYTIC THERAPY IN PATIENTS DIAGNOSED WITH ACUTE MYOCARDIAL INFARCTION IN A GENERAL HOSPITAL ${ }^{1}$
}

\author{
Luis Antônio Muller ${ }^{2}$ \\ Eneida Rejane Rabelo ${ }^{3}$ \\ Maria Antonieta Moraes ${ }^{4}$ \\ Karina Azzolin ${ }^{5}$
}

Muller LA, Rabelo ER, Moraes MA, Azzolin K. Delay factors on the administration of thrombolytic therapy in patients diagnosed with acute myocardial infarction in a general hospital. Rev Latino-am Enfermagem 2008 janeiro-fevereiro; 16(1):52-6.

Objective: To identify factors that delay the onset of thrombolysis in patients with acute myocardial infarction (AMI). Methods: A cohort study was carried out with 146 patients, each diagnosed with AMI and subjected to thrombolytic therapy. The data was extracted from medical records between January 2002 and December 2004. Results: The average age of the studied population was $57.5 \pm 9$ years, $64.4 \%$ were male. The average time between the onset of pain and arrival at the hospital was $254.7 \pm 126.6$ minutes, $28.1 \%$ used an ambulance for the trip to the hospital, the door-toelectrocardiogram time averaged $19.4 \pm 7.3$ minutes and the door-to-needle time was $51.1 \pm 14.9$ minutes. There was no significant difference between the time of arrival to the hospital and the method of transportation used $(P=0.81)$, and those seen by cardiologists and during the nightshift had a reduction in the door-to-needle time, respectively $(P=0.014)$ and $(P=0.034)$. Conclusions: Study results show that the delay in the search for medical service, and the long time taken from door-to-electrocardiogram and to reach the AMI diagnosis were the factors involved in the delay of thrombolytic treatment.

DESCRIPTORS: myocardial infarction; thrombolytic therapy; emergency medical services

\section{FACTORES QUE ATRASAN LA ADMINISTRACIÓN DE TROMBOLÍTICO EN PACIENTES CON DIAGNÓSTICO DE INFARTO AGUDO DEL MIOCARDIO ATENDIDOS EN UN HOSPITAL GENERAL}

Objetivo: Identificar los factores que retardan el inicio de la trombolisis en pacientes con IAM. Métodos: Estudio de coorte, en 146 pacientes, con diagnóstico de IAM sometidos a la terapéutica trombolitica. Los datos fueron extraídos de prontuarios, entre enero de 2002 y diciembre de 2004. Resultados: El promedio de edad fue de 57,5 \pm 9 años y 64\% eran del sexo masculino. El tiempo promedio transcurrido entre el inicio del dolor y la entrada al hospital fue de 254,7 \pm 126,6 minutos; $28 \%$ utilizaron la ambulancia como medio de transporte; el tiempo promedio porta ECG (tiempo porta ECG: intervalo entre el ingreso del paciente al hospital y la realización del electrocardiograma) fue de 19,4 \pm 7,3 minutos y el tiempo porta aguja de 51,1 \pm 14,9 minutos (tiempo porta aguja: intervalo entre la entrada del paciente al hospital y la administración del trombolítico). No hubo diferencia significativa entre el tiempo de ingreso al hospital y los medios de transporte utilizados. Los pacientes atendidos por un médico cardiólogo y durante el turno de la noche tuvieron una reducción en el tiempo porta aguja, respectivamente, de $(P=0,014)$ y $(P=0,034)$. Conclusiones: Los resultados del estudio demuestran que la demora en el ingreso al servicio médico, el tiempo porta electrocardiograma y el tiempo para diagnosticar el IAM, fueron los factores que determinaron el retardo de la administración del trombolítico.

DESCRIPTORES: infarto del miocardio; terapia trombolítica; servicios médicos de urgencia

\section{FATORES QUE RETARDAM A ADMINISTRAÇÃO DE TROMBOLÍTICO EM PACIENTES COM DIAGNÓSTICO DE INFARTO AGUDO DO MIOCÁRDIO ATENDIDOS EM UM HOSPITAL GERAL}

Objetivo: Identificar fatores que retardam o início da trombólise em pacientes com IAM. Métodos: Estudo de coorte, com 146 pacientes, com diagnóstico de IAM submetidos à terapêutica trombolítica. Os dados foram extraídos de prontuários, entre janeiro de 2002 e dezembro de 2004. Resultados: A média de idade foi de 57,5 \pm 9 anos, 64\% sexo masculino. O tempo médio entre o início da dor e a chegada ao hospital foi de 254,7 $\pm 126,6$ minutos, 28\% utilizaram a ambulância para o deslocamento, o tempo porta-eletrocardiograma médio de $19,4 \pm$ 7,3 minutos e tempo porta-agulha de 51,1 $\pm 14,9$ minutos. Não houve diferença significativa entre o tempo de apresentação ao hospital e o meio de transporte utilizado. Os pacientes atendidos por cardiologistas e no turno da noite tiveram uma redução no tempo porta-agulha, respectivamente $(P=0,014)$ e $(P=0,034)$. Conclusões: Os resultados do estudo demonstram que a demora na chegada ao serviço médico, tempo porta-eletrocardiograma e tempo para diagnosticar o IAM, foram os fatores envolvidos no retardo da administração de trombolítico.

\footnotetext{
${ }^{1}$ Paper extracted from the Monograph presented in the Lato Sensu Graduate Course; ${ }^{2}$ RN, Specialist in Urgency, Emergency and Trauma, Pos Graduate Student, Fundação Universitária de Cardiologia, RS, Brazil, e-mail: pesquisa@cardiologia.org.br; ${ }^{3}$ RN, Hospital das Clinicas de Porto Alegre, Ph.D. in Biological Sciences: Physiology, Adjunct Professor, Rio Grande do Sul Federal University, Brazil; ${ }^{4}$ RN, M.Sc. in Health Sciences: Cardiology; ${ }^{5}$ RN, Hospital Mãe de Deus, M.Sc. in Health Sciences: Cardiology, Faculty, Centro Universitário Metodista IPA, RS. Faculty. Instituto de Cardiologia/Fundação Universitária de Cardiologia, Brazil
} 


\section{INTRODUCTION}

Cardiovascular diseases are the major cause of death in developed and developing countries, representing $31.8 \%$ of deaths causes in Brazil $^{(1)}$. Over $50 \%$ of these deaths are sudden and occur before the patient arrives to the hospital, that is, in the pre-hospital stage. Of these deaths, $40 \%$ to $65 \%$ occur in the first hour after the onset of the symptoms, and approximately $80 \%$ occur in the first 24 hours $^{(2)}$.

As of the early 1980s, there has been full confirmation of experimental evidence showing the benefits of replacing the coronary artery related to the infarction. Fibrinolytics and mechanical interventions have been used to reestablish the blood flow through Percutaneous Transluminal Coronary Angioplasty (PTCA), normally followed by stent ${ }^{(2)}$.

However, thrombolysis is still the most common treatment used in myocardial infarction. The greatest benefit is obtained when the fibrinolytic agents are administered right after the onset of the symptoms, especially within the first hour after the event. It is estimated that the benefit is a reduction of $1 \%$ in death by acute myocardial infarction (AMI) for every hour saved when administering the drug within the first six hours ${ }^{(3)}$.

Yet, it is observed that in some health services, thrombolysis is carried out after a longer period than that recommended because of various factors.

A study showed some factors which determine the delay in starting the thrombolytic therapy, which include the delay in: contacting the Emergency Medical Service, transporting the patient, admitting the patient in the emergency department, initial assessment of the patient including obtaining and interpreting the electrocardiogram, and the delay in preparing the drug" ${ }^{\prime \prime 2}$.

This study also showed that intrahospital factors contribute with $59 \%$ of the time spent between the onset of symptoms and the beginning of the thrombolytic therapy. After the patient arrives to the hospital, about 20 minutes are spent waiting to obtain an electrocardiogram and it takes another 70 minutes until starting the administration of the thrombolytic ${ }^{(2)}$.

Therefore, it is fundamental for the health team to make an effort to develop health care protocols to improve the quality of emergency services. This would help to provide quicker service to patients with heart disease, which would significantly reduce the time spent between the onset of the event and the myocardial reperfusion.

Bearing this concern, this study aims to identify the factors that are likely to delay the onset of thrombolytic administration in patients diagnosed with Acute Myocardial Infarction in a general hospital in the interior of Rio Grande do Sul State.

\section{PATIENTS AND METHODS}

This retrospective cohort study took place from January 2002 to December 2004, and included 146 patients (94 men and 52 women) hospitalized in a general hospital in the state of Rio Grande do Sul This study was approved by the Hospital's Research and Ethics Committee and used a commitment term to use the data obtained from the records.

The hospital receives an average of 260 patients per year with AMI. The population of this study consisted of all patients bearing AMI with ST segment elevation that received thrombolytics in the Intensive Care Unit in this period, after diagnosis and preparation for the therapy in the Emergency Service of the same hospital. Five (5) patients were excluded due to lack of record data: three (3) patient records did not state the time of the first electrocardiogram, and two (2) did not state the time of admission to the emergency service.

The data collection was performed through the analysis of patient records, obtained with the Department of Medical File and Statistics, and the researcher completed a specific form in April and May 2005.

The diagnostic criteria for AMI with ST segment elevation were those used in the institution, and this data was collected from the medical evolution. Data regarding the sample characterization, starting time of chest pain, mode of transportation to the hospital, and type of initial treatment (cardiology or clinical) were collected from the medical record that is completed as part of the patient admission routine. The time it took to perform the first ECG was obtained considering the time of admission and the time stated in the first electrocardiographic record.

It was not possible to quantify exactly how long the patient had to wait for a bed in the ICU due to limitations of this type of research. 
The time between diagnosis and the onset of thrombolysis was obtained considering the confirmatory electrocardiographic record and the time that the therapy was started, as stated on the medical prescription. The door-to-needle time was obtained considering the time of admission and the starting of therapy.

Statistical analysis was carried out using SPSS 12.0 software. The sample consisted of 146 patients for an alpha of $0.05 \%$ and beta of $0.02 \%$ and a proportion of $50 \%$ of delay factors, with a safety margin of $10 \%$. Patient records were selected by convenience, according to the diagnosis for AMI with ST segment elevation and medical prescription for thrombolytics.

The data were described with averages and standard deviation for continuous variables and proportions for categorical variables. ANOVA was used to compare the averages of electrocardiogram times and the moment that the therapy was started, according to the mode of transportation. Student's ttest was used to compare the times regarding the type and shift of medical care. In addition, a dispersion graphic was designed to compare times using Pearson's correlation coefficient.

\section{RESULTS}

The 146 patients bearing AMI with ST segment elevation were between 30 and 80 years old (average age $=57)$. Most of them sought the hospital emergency department complaining of chest pain, and $48 \%$ were locals.

Table 1 presents a summary of sample characteristics.

Table 1 - Clinical characteristics of patients seen in the emergency department $(n=146)$

\begin{tabular}{lc}
\hline \multicolumn{1}{c}{ Clinical Characteristics } & $\%$ \\
\hline Age $^{* \star}$ & $57.5(9)$ \\
Male & 64.4 \\
Arterial hypertension $^{*}$ & 62.3 \\
Diabetes mellitus* $^{*}$ & 37 \\
Smoking $^{*}$ & 40.4 \\
Dislipidemia* $^{*}$ & 19.9 \\
Obesity $^{*}$ & 16.4 \\
Sedentariness $^{*}$ & 21.9 \\
Previous AMI $^{*}$ & 10.3 \\
Other comorbidities $^{*}$ & 23.3
\end{tabular}

* Comorbidity history; **Data presented with average and standard deviation
Regarding the mode of transportation to the hospital, $28.1 \%$ came by ambulance, $57.5 \%$ by their own means, and $14.4 \%$ of the records did not specify the mode of transportation. Of these patients, 74\% were seen by a cardiologist, and $54.8 \%$ arrived in the morning shift.

When patients arrived at the emergency department, they were fist seen by the nursing team. Then, after medical care, they were forwarded to get an electrocardiogram.

Table 2 shows the average times, in minutes, of the care provided. It should be stressed that the maximum time registered to start the thrombolytic therapy was 109 minutes.

Table 2 - Description of the time elapsed between AMI diagnosis and start of thrombolytic therapy

\begin{tabular}{lc}
\hline \multicolumn{1}{c}{ Average time (in minutes) } & Average (SD) \\
\hline $\begin{array}{l}\text { Time between onset of symptoms and seeking emergency } \\
\text { department }\end{array}$ & $254.7(126.6)$ \\
Door-to-electrocardiogram time* & $19.4(7.3)$ \\
Time between diagnosis and starting thrombolytic therapy & $32.0(12.8)$ \\
Door-to-needle time* & $51.1(14.9)$ \\
\hline
\end{tabular}

* As of patient arrival to emergency department

There was no statistically significant difference between the times for ECG performance and doorto-needle time regarding the mode of transportation to the hospital. In other words, patients who came by ambulance $(28.1 \%)$ did not start therapy sooner.

Table 3 shows comparisons among the type of care provided.

Table 3 - Door-to-electrocardiogram and door-toneedle time, according to the shift and medical specialization

\begin{tabular}{ccccc}
\hline $\begin{array}{c}\text { Average time } \\
\text { (in minutes) }\end{array}$ & Day shift & Night shift & Cardiologist & $\begin{array}{c}\text { Non } \\
\text { Cardiologist }\end{array}$ \\
\hline $\begin{array}{c}\text { Door to } \\
\text { electrocardiogram* }\end{array}$ & $18.7(8.3)$ & $19.1(7.8)$ & $18.9(7.2)$ & $20.7(7.3)$ \\
Door to needle* $^{*} 52.0(5.64)$ & $46.0(11.92)$ & $49.38(13.53)$ & $57(22.09)$ \\
\hline * Data presented with average and standard deviation & \\
The door-to-needle time was shorter in
\end{tabular}

patients seen by cardiologists compared to those seen by non-cardiologists $(P=0.014)$.

Door-to-needle time was also significantly shorter among patients seen in the night shift $(P=0.034)$. There was no difference among other times in day or night shifts. 


\section{DISCUSSION}

From the moment a patient with chest pain arrives to the hospital, there is a race against time from the moment of diagnosis until the therapy is started. Reperfusion strategies aim to restore the flow with early coronary replacing, to limit infarction size, and reduce myocardial damage, consequently improving the ventricular dysfunction and the patient's life expectancy ${ }^{(3)}$. This paper has the purpose to identify, by means of a retrospective cohort study, the factors that delay the administration of thrombolytics in a general hospital.

The benefit of myocardial reperfusion are time-dependant; the earlier the coronary flow is reestablished, the higher the benefit for the patient ${ }^{(2)}$. One of the factors responsible for the delay in providing care to patients with acute coronary disease is the lack of knowledge or denial of the heart attack by patients and relatives. This study confirms the referred data, showing that the average time between the onset of symptoms and admission to the hospital is 254.7 (126.6) minutes. This shows there is a considerable initial delay in ischemic lesion treatment. This result may be associated with the fact that $48 \%$ of patients are locals, and $57.5 \%$ used their own means of transportation to get to the hospital $^{(2)}$. A previous study shows that the main discomfort caused by infarction is the rupture with the daily life; this may justify the denial of a heart $\operatorname{attack}^{(4)}$.

The I Chest Pain Guideline ${ }^{(5)}$ recommends that every patient with suspected Acute Coronary Syndrome (ACS) in the emergency room should get an ECG immediately, in the first 5 to 10 minutes after arriving at the hospital. Of the 146 patients studied, the door-to-electrocardiogram time was 19.40 (7.27) minutes. One of the reasons for this delay is that the exam is performed only upon medical order, after assessment.

Since the nursing team is responsible for the first part of the assessment, it is important for one specific nurse to screen the cases and determine emergency care procedures through and initial assessment and requesting an ECG. This would provide agility, quickness, and effectiveness in the care process.

It would be ideal that the time between patient arrival and thrombolytic infusion were no more than 30 minutes (door-to-needle time) ${ }^{(6)}$, because the earlier the artery is replaced, the higher the heart muscle mass saved from necrosis, thus ensuring a better prognostic. In this study, the doorto-needle time was 51.14 (14.91) minutes. One of the probable delay factors was time it took to transfer patients to the Intensive Care Unit (ICU), where the thrombolytic is administered. Since it is not possible to verify the time, it took between reaching a diagnosis and the patient being transferred, it is impossible to test this association. This is one the limitations of this study because it was not possible to check this variable precisely, since this is a retrospective study.

There is reduction in the thrombolytic therapy administration time when it is administered in the emergency department. A previous study showed a reduction in 58 minutes when these procedures start to be done in the emergency department rather than exclusively in the $\mathrm{ICU}^{(7)}$. Another study ${ }^{(8)}$ found an increase from $3.4 \%$ to $12 \%$ in the death rate when the therapy was administered in the emergency department.

Studies $^{(5,7)}$ suggest that patients who got to the hospital by ambulance present a shorter door-toneedle time. In the present study, $28.1 \%$ of the patients got to the hospital by ambulance, but the total time taken to start the therapy was not reduced $(P=0.81)$. Studies have shown a reduction in mortality after thrombolytic therapy in patients that received pre-hospital care ( $8 \%$ versus $13 \%)(P=0.04)^{(9-10)}$.

Another factor reported as a reducing factor in door-to-needle time was night shift care. This was confirmed in the present study, in which the door-toneedle time was 29.5 (8.7) minutes versus 34 (15.1) in the day shift $(P=0.034)$. This factor can be considered a time reducer, considering that during the night shift there is a reduction in the number of patients, thus care is provided faster.

A study performed at the Vancouver General Hospital ${ }^{(11)}$ showed an average reduction in 67 minutes in the door-to-needle time in patients seen by cardiologists. Patient care performed by a specialized physician is fundamental to reduce the time used to determine the therapy and starts thrombolysis. In addition, the present study results shows there was a significant reduction in door-to-needle time in the care offered by cardiologists [49.38 (13.53) vs. 57 (22.09)] $\mathrm{P}=0.015$. 


\section{CONCLUSIONS}

This study showed that the factors that contributed with the delay in administering thrombolytic therapy in the studied patient group were the delay in seeking medical care, the door-toelectrocardiogram time, and the initial consultation with a non-cardiologist physician. It should be stressed that a prospective study is called for in order to perform a better validation of the data presented in this study. Furthermore, institutional measures should be taken to reduce door-to-needle time and improve patients' life expectancy, such as implementing health care protocols for patients with chest pain and administering thrombolytics in the emergency department.

\section{REFERENCES}

1. Ministério da Saúde (BR) [homepage na Internet]. Brasília: Ministério da Saúde; [Acesso em 2007 julho 25]. Indicadores de Saúde - Datasus 2004; [13 telas]. Disponível em: URL: http://tabnet.datasus.gov.br/cgi/tabcgi.exe?idb2006/c04.def. 2. Timerman S, Marques FBR, Pispico A, Ramires JAF. Tratamento pré-hospitalar da síndrome isquêmica aguda com supradesnivelamento de segmento ST: Já temos suficiente evidência para implantar de rotina?. Rev da Soc Cardiol 2004 novembro; 14(6):868-86.

3. Piegas LS, Timerman A, Nicolau JC, Mattos LA, Rossi Neto JM, Feitosa G. III Diretrizes para o tratamento do infarto agudo do miocárdio. Arq Bras Cardiol 2004 setember; 83(Suppl 4):3-86. 4. Mussi FC. O infarto e a ruptura com o cotidiano: possível atuação da enfermagem na prevenção. Rev Latino-am Enfermagem 2004 setembro-outubro; 12(5):751-9.

5. Bassan R, Pimenta L, Leães PE, Timerman A. I Diretriz de dor torácica na sala de emergência. Arq Bras Cardiol 2002 August; 79(Suppl 2):1-22.

6. Baruzzi ACA. Infarto agudo do miocárdio exige rapidez no tratamento. Prática Hospitalar [seriado online] 2002 setembro/outubro; (4):23. Disponível em:

URL: http:""www.praticahospitalar.com.br..

7. McLean S, O'Reilly M, Doyle M, Rathaille $M$. Improving Door-to-Drug time and ST segment resolution in AMI by moving thrombolysis administration to the Emergency Department. Accid Emerg Nurs 2004 January; 12(1):2-9.

8. Hourigan C, Mountain D, Langton P, Jacobs IG, Rogers IR, Jelinek GA et al. Changing the site of delivery of thrombolytic treatment for acute myocardial infarction from the coronary care unit to the emergency department greatly reduces door to needle time. Heart 2000 August; 84(2):157-63.

9. Mathew TP, Menown IB, McCarty D, Gracey H, Hill L, Adgey AA. Impact of pre-hospital care in patients with acute myocardial infarction compared with those first managed inhospital. Eur Heart J 2003 January; 24(2):161-71.

10. Goodacre S, Kelly AM, Kerr D. Potential impact of interventions to reduce times to thrombolysis. Emerg Med J 2004 September; 21(5):625-9.

11. Zed PJ, Abu-Laban RB, Cadieu TM, Purssell RA, Filiatrault L. Fibrinolytic administration for acute myocardial infarction in a tertiary ED: factors associated ted with an increased doorto-needle time. Am J Emerg Med 2004 May; 22(3):192-6. 